\title{
Islamic LaW From the Internal Point of View
}

\author{
Haider A. Hamoudi \\ University of Pittsburgh
}

\begin{abstract}
Haider Hamoudi notes the different perspectives lawyers and historians employ in making sense of the law. Invoking H.L.A. Hart's famous distinction between "internal" and "external" points of view with respect to law and legal rules, Hamoudi describes lawyers as primarily adopting the former, and historians, the latter point of view. This is not to suggest that lawyers do not take history into consideration, but rather to mean that when they do, their focus is results oriented in that they use history to understand the ultimate endpoint, the contemporaneous meaning of a legal rule or institution. Hamoudi observes two consequences emanating from lawyers' adoption of the internal view that puts lawyers somewhat at odds with the demands of historical method and meaning. While deliberately omitting discussion on the normative desirability of either method, Hamoudi concludes by observing value in merely pointing out the differences between the internal and external viewpoints of law and history, respectively, to help expose "our own biases and assumptions."
\end{abstract}


The begin this short contribution with a confession - I am not an historian. I am not even a legal historian. I am a lawyer, devoting much of my professional life to understanding and analyzing the methods by which contemporary courts and other legal institutions use Islamic law in their decision making, and from time to time using those same methods to make arguments of my own before other courts and legal institutions. The methods thus used, and the arguments thus deployed, in my experience seem to strike many in the humanities and social sciences as acontextual, misconceived, and distorting. My submission is that this perception arises not because there is anything particularly wrong with the way in which modern courts use Islamic law in broad conception, but rather because the disciplines approach the study of the past differently.

The great legal positivist H.L.A. Hart points out that the way in which legal rules are understood within law is distinct from the manner in which they are understood in other disciplines. To quote Hart directly,

[I]t is possible to be concerned with the rules, either merely as an observer who does not himself accept them, or as a member of the group which accepts and uses them as a guide to conduct. We may call these respectively the "external" and the "internal" points of view. ${ }^{1}$

Lawyers and judges almost without exception adopt this "internal point of view" when crafting arguments or making decisions. The foundational assumption underlying this perspective is that the law is capable of establishing its own normative rules, and policing its own boundaries and categories, on its own terms, without need of validation from other disciplines.

To be clear, lawyers and judges do make use of history, and other social sciences, when crafting legal argument. However, they use them as an instrument, rather than approaching the disciplines on their own terms and on the basis of their own founda1961), 89 .

1 H.L.A. Hart, Concept of Law (Oxford: Oxford University Press, 
tional assumptions. Ronald Dworkin - who famously took aim at Hart's theory of legal positivism ${ }^{2}$ - largely agrees with Hart on the distinction between internal and external perspectives. Dworkin describes those adopting the law's internal perspective and their use of the social sciences (with particular reference to history), as follows:

Their interest is not finally historical, though they may think history relevant; it is practical.... They do not want predictions of the legal claims they will make but arguments about which of these claims is sound and why; they want theories not about how history and economics have shaped their consciousness but about the place of these disciplines in argument about what the law requires them to do or have. ${ }^{3}$

To illustrate in the context of Islamic law, it would be exceedingly rare for a lawyer making an argument in a modern court to be concerned with the progressive stabilization and institutionalization of the Sunn̄ madhhabs and parallel Shī'î institutions from the twelfth through fifteenth centuries, to borrow from the themes of Professor Katz's scintillating article on that very subject. ${ }^{4}$ Lawyers do not think they need to know much about the development of lawmaking institutions in particular epochs in the premodern world in order to know how to make arguments from the rules of Islamic law as promulgated by various jurists within the institutions themselves. Judges, similarly, do not find this sort of historical contextualization useful as they render decisions based on Islamic law.

Similarly, social science approaches to the law that seem to tear apart the entire foundation upon which an entire area of

2 Scott Shapiro, "The 'Hart-Dworkin' Debate: A Short Guide for the Perplexed," in Ronald Dworkin, ed. Arthur Ripstein (New York: Cambridge University Press, 2007), 22-55. Press, 1986), 13.

3 Ronald Dworkin, Law's Empire (Cambridge, MA: Harvard University

4 See Marion Katz, "The Age of Development and Continuity, 12th15th Centuries CE," in The Oxford Handbook of Islamic Law, eds. Anver Emon and Rumee Ahmed (Oxford: Oxford University Press, 2018). 
law operates are unlikely to gain very much purchase from those adopting the internal perspective. By way of example, Mariam Sheibani, Amir Toft, and Ahmed El Shamsy richly engage the reliability of the traditional Muslim account of the genesis of Islamic law in a recent, laudable article. They note as follows:

This traditional account, in a nutshell, says that Islamic law originated in the rules and instructions propounded by Muhammad, and that after the exodus to Medina and the establishment of a Muslim polity these rules grew into an extensive body of laws rooted in the Qur'an. After Muhammad's death, his successors continued to implement the Qur'anic laws as well as others based on the Prophet's precedent. In addition, they solved issues that were not explicitly covered by the former two sources by employing individual reasoning $\left(r a^{\prime} y\right)$. Some of Muhammad's companions who were recognized for their legal acumen settled in the newly founded garrison towns, establishing regional traditions of legal learning in these locations. Between the second quarter of the second Islamic century and the middle of the third..., a handful of prominent jurists systematized earlier legal thought and laid the foundations for enduring legal schools with their own legal literatures. Within this traditional narrative, the aspects that have prompted extensive debate concern the following questions: whether the Qur'an actually served as a source for the early jurists; whether the Hadith reports contain authentic information regarding Muhammad's sayings and actions (and if they do not, when and how they became attributed to him); whether and how the regional legal traditions were transformed into legal schools centered around particular individuals; and how the nature of legal reasoning changed within this period. ${ }^{5}$

$5 \quad$ Mariam Sheibani, Amir Toft and Ahmed El Shamsy, "The Classical Period: Scripture, Origins, and Early Development," in The Oxford Handbook of Islamic Law, eds. Anver Emon and Rumee Ahmed (Oxford: Oxford University Press, 2018), 403-04. 
The authors describe the validity of these truth claims as a "central" debate in the historical scholarship. This is noteworthy, because the debate is of diminished value to those adopting the law's "internal point of view." The governing assumption is that the traditional account is accurate. It could not be otherwise. To question the centrality of the Qur'ān to the content of the law or to suggest that almost none of the Sunna came from the Prophet Muhammad directly, would be to undermine the entire edifice upon which the court relies in defining the normative boundaries of Islamic law, and in defining and redefining its categories.

Of course, the work of the historian and the lawyer can overlap. For example, where the Pakistani Supreme Court claims that the proper punishment for zina ' is lashing, and not stoning, and casts doubt on hadith that seem to suggest otherwise, ${ }^{6}$ the plausibility of the legal argument in many ways overlaps with the historicity of the claim. Yet the disciplines, each equally valuable in its own right, are quite different, and in a way that can render the one baffling and well-nigh incomprehensible to the other.

In my experience, within the Islamic context, there are two consequences to the law's internal approach that render it particularly challenging to understand when adopting the external perspectives of the social sciences. The first of these is the law's tendency to decontextualize legal rules. The assumption that the law establishes its own normative boundaries and categories carries with it a consequent assumption that there is a certain stability to legal doctrine, a pith and pit to legal rules that carry across time and place, and that a judge or lawyer may access to advance a particular claim or make a particular decision. The precise historical context in which these rules were issued is, as a result, usually of limited worth.

To illustrate with an example from Islamic finance, consider Muftī Taqi Usmani's now famous article criticizing particular forms of $s u k \bar{u} k$ as failing to meet minimum standards of shari ' $a$ compliance. In this approximately twenty four page work, in order to fashion the legal arguments that he does,

6 Hazoor Bakhsh v. Federation of Pakistan (1981 PLD FSC 145). 
Usmani makes voluminous references not only to Qur'ān and Sunna, but also to jurists as varied as the Hanbali jurist Ibn Qudāma (d. 620/1223), the hadīth scholar Ibn Hajar al- 'Asqalānī (d. 852/1449), the modern fiqh commentator Muștafā al-Zarqā (1904-1999), and Mālik b. Anas (d. 179/795). ${ }^{7}$ An historian friend of mine immediately dismissed this sort of patchwork argument stitched together across over 1500 years of jurisprudence, from hadīth scholar to Hanbali jurist to the eponym of the Mālikī school and beyond, as patently ridiculous. This was, to her mind, yet another results-oriented attempt to find some way to bless modern Islamic finance transactions that were designed to mimic conventional ones in all but form. The irony was that in fact Usmani was doing something very nearly the opposite, in that he was seeking to limit the variations of $s u k \bar{u} k$ that had proliferated and that he felt were pulling Islamic finance away from what he described as the "higher purposes of Islamic economics." 8

The more salient point for these purposes is that Usmani's approach did not strike very many lawyers I know as being particularly unusual or problematic, whether those lawyers were well schooled in fiqh or not. Indeed, when I communicated the objection to a partner at my former law firm who was deeply engaged in Islamic finance transactions, he was kind enough to send back to me, without comment, a brief we had worked on together concerning whether or not our client, a software developer, was responsible to their contracting partner, a software distributor, for particular types of consequential damages that had arisen from an alleged bug in the software. The brief cited a mid-nineteenth century English case, the Uniform Commercial Code, commentaries to the Uniform Commercial Code written in the middle of the twentieth century, and cases from the respective jurisdictions of New York, New Jersey, California, and Florida over the past half century. I can certainly appreciate and see the value in an external disciplinary perspective that might

$7 \quad$ Muftī Muhammad Taqi Usmani, Sukuk and their Contemporary Applications (Al-Qalam, Al-Qalam Sharī‘ah Scholar Panel, 2008), http://alqalam.org. uk/wp-content/uploads/2017/07/Sukuk.pdf

8 Ibid, 23. 
ask precisely why a case decided when it was legal to purchase and sell human beings could shed light on damages for which a software developer might be liable. The concerns that animate an antebellum court respecting damages for contract breaches surely bear no resemblance to those that would motivate a twenty-first century court dealing with software.

For whatever it is worth, our own internal perspective would be that the common law has long established a principle that applies across time and space that a party is responsible for damages that arise from a breach of contract, and that principle is that the breaching party is only responsible for those damages which it knew, or should have known, were a probable result of the breach. The use of material across different jurisdictions and eras is in this context quite intentional-to show the depth and tenacity of the principle.

I have seen courts use this approach in Islamic law with some frequency. An Iraqi court denying recognition of a conversion out of Islam, and an Egyptian court seeking to demonstrate that Nasr Abu Zayd's writings are acts of unambiguous apostasy, both cited foundational text and jurists across madhhabs and eras to demonstrate the universality of their respective arguments. ${ }^{9}$ (The Egyptian court even went so far as to cite Shī'i jurists it would barely recognize in almost any other context.)

To be clear, the law's tendency to eschew historical contextualization is not universal. If contextualization will help construct a legal argument-by providing an avenue through which an authority might be distinguished or discarded, for examplethen a court will adopt it. Faced with the inconvenient fact that Hanafĩ jurists never permitted a child to receive financial support from a father prior to the date of instituting a claim for such support, the Egyptian Supreme Constitutional Court turned, inter alia, to a historical contextualization. Specifically, the Court suggested that the juristic rule arose at a time when the filing of such suits was largely unnecessary and, in the rare

9 Case 318/2000 of the General Panel of the Court of Cassation (Iraq); Case No. 287 of Judicial Year 11, District 14, Personal Status Appeals Court of Cairo, decided June 14, 1995 (Egypt). 
event that it proved necessary, the claims were easier to make. ${ }^{10} \mathrm{I}$ would note that the contextualization in such instances is not understood to undermine the stability of legal doctrine so much as demonstrate its continuous evolution within self-defined normative boundaries. Legal rules exist within the system to serve certain aims, and adapt to continue to serve those aims across place and time. In those instances where the underlying purposes are no longer served by the rules due to significant shifts in social conditions, they may be discarded.

This leads to the second consequence of the internal point of view that can be harder for outsiders to grasp, which is the fact that the better authority tends to be the more recent. In some ways, this seems counterintuitive-how can the best authority to demonstrate the validity of a particular issuance of sukūk, for example, be anything other than revelatory text? How could it be that a lawyer seeking to persuade a $\operatorname{shar}^{6} a$ review board of $\operatorname{shari}^{-} a$ compliance turns first to the Standards of the Accounting and Auditing Organization of Islamic Financial Institutions, rather than to Qur'ānic verse or Sunnaic pronouncement, or at least the interpretations of early jurists?

Again, the challenge is by no means unique to Islamthe same argument could be made vis-à-vis a constitutional court which turns to its precedent first, rather than to the text of the constitution it claims to be interpreting. In neither case, of course, is a court suggesting that the original texts are somehow unimportant - to the contrary, they are the foundation upon which the doctrine is built. For this reason, it would be exceedingly rare for a court interpreting Islamic law (or a constitutional court interpreting a constitutional provision) not to cite the relevant, original text.

Still, the meaning of that text, and the manner of its application, by necessity adapt over time to address broadly different facts and circumstances in disparate places at disparate times. And it is therefore the evolution of the doctrine, presumed to be stable, and presumed to proceed from the original meanings the

10 Decision 29 of Judicial Year 11, Supreme Constitutional Court of Egypt, decided March 29, 1994. 
text offers, that is of more interest to the lawyer and the court, because the later authorities almost surely speak more closely and more directly to the matter with which the court grapples.

Pennsylvania has a series of rules, part of what is known as the Statute of Frauds, that requires that certain contracts be in writing in order to be enforceable. Many of these rules predate the founding of the United States. Indeed, for contracts for the sale of land, the rules specifically indicate they take effect only as to contracts entered into after April 10,1772. It is written in language that is slightly archaic and challenging for many of my law students to decipher. I suspect the same might be true for quite a few lawyers admitted to the Pennsylvania bar. ${ }^{11}$ This is of little moment. To paraphrase Frederic Maitland, lawyers only presume to understand what a centuries old statute meant in its time, and give little thought to it in the vast majority of cases. Instead, "it is the ultimate result of the interpretations of the statute by the judges of twenty generations" in which they are truly interested. Maitland continues:

The more modern the decision the more valuable for [the lawyer's] purpose. That process by which old principles and old phrases are charged with a new content is from the lawyer's point of view an evolution of the true intent and meaning of the old law; from the historian's point of view, it is almost of necessity a process of perversion and misunderstanding. ${ }^{12}$

The same might readily be said of a Kuwaiti court grappling with the shari' 'a compliance of a particular șukuk issuance, an Egyptian court deciding whether or not a husband's nafaqa obligation extends to a certain type of herbal medicine, or an Indonesian court considering how to apply a prohibition on khulwa to a couple on a motorcycle who stopped on the side of the road for a period of several minutes. The authorities with which the

1133 PA CS 1-3.

12 Frederic Maitland, "Why the History of English Law is not written," in The Collected Papers of Frederic William Maitland, ed. H.A.L. Fisher (Cambridge: Cambridge University Press, 1911), 222. 
court will engage most intently will be the most recent, because they speak most directly to the question that the court seeks to resolve.

The purpose of these brief remarks is not to make some sort of anti-intellectual claim respecting whose perspective is the better one. It suffices to note that each adds value in its own right. I have little patience for a lawyer or judge so incurious as to be unwilling even to consider external perspectives that challenge the stability of the doctrine, or provide contextualization to demonstrate, for example, that the doctrine arose to privilege certain groups over others. My only purpose was to offer my own views of how lawyers and judges understand Islamic law, from their own insider's perspective, in the hopes that it might enlighten those less familiar with our own biases and assumptions. 